\title{
SISTEM OTOMASI RUANGAN DENGAN RASPBERRY PI BERBASIS MOBILE WEB STUDI KASUS: (LEMBAGA KURSUS CODY APP ACADEMY)
}

\author{
Aditya Mirza Bahari ${ }^{1}$, Nenny Anggraini ${ }^{2}$, Siti Ummi Masruroh ${ }^{3}$ \\ Teknik Informatika, Fakultas Sains dan Teknologi \\ Universitas Islam Negeri Syarif Hidayatullah Jakarta \\ mirzabahari@gmail.com, nenny.anggraini@uinjkt.ac.id, luhkesuma@uinjkt.ac.id
}

\begin{abstract}
ABSTRAK
Cody App Academy adalah sebuah tempat kursus berbasis teknologi di Bintaro, Jakarta Selatan. Berdasarkan observasi yang dilakukan penulis, Cody masih menerapkan cara manual untuk menyalakan dan mematikan listrik. Selain itu, hasil dari wawancara oleh pengelola Cody, dapat disimpulkan bahwa hal ini berdampak terhadap efisiensi penggunaan arus listrik yang ada di Cody, yang berkaitan langsung dengan besar atau kecilnya tagihan listrik yang harus dibayarkan oleh pengelola Cody. Maka penulis mengusulkan sebuah solusi berupa prototipe Sistem Pengendali Ruangan dengan teknologi motion berbasis mobile web yang merupakan aplikasi yang dapat merubah sistem manual menjadi sebuah sistem home automation. Aplikasi ini akan secara otomatis mematikan arus listrik ketika ruangan sedang kosong, dilihat dari tidak terdeteksinya gerakan dalam rentang waktu lebih dari 10 menit. Metode pengumpulan data yang yang penulis gunakan adalah pengumpulan data primer dan sekunder yang terdiri dari observasi, wawancara dan studi literatur sejenis. Sedangkan untuk metode pengembangan aplikasi adalah prototipe evolusioner dengan 4 tahap yang mencakup analisis kebutuhan pengguna, membuat satu prototipe. Hasil dari penelitian ini adalah penerapan home automation yang berupa Sistem Pengendali Ruangan dengan teknologi motion selama jangka waktu 2 bulan berbasis mobile web terbukti membuat penggunaan listrik di Cody lebih efisien berdasarkan perbandingan tagihan listrik sebelum dan sesudah menggunakan sistem yang penulis usulkan. Hal ini dapat terlihat dari perubahan signifikan pada biaya listrik yang harus dibayarkan Cody per bulan yakni sejumlah $20 \%$ lebih efisien dibandingkan tanpa menggunkan sistem yang penulis usulkan.
\end{abstract}

Kata Kunci: Otomasi Rumah, Smart Room, Motion, Mobile Web Application

\begin{abstract}
Cody App Academy is a technology-based course place in Bintaro, South Jakarta. Based on observations made by the author, Cody is still applying the manual way to turn on and turn off the electricity. In addition, the results of interviews by Cody's managers, it can be concluded that this impacts on the efficiency of the use of electric current in Cody, which is directly related to the large or small bill of electricity that must be paid by the manager of Cody. So the author proposed a solution in the form of prototype Space Control System with motion technology based mobile web which is an application that can change the manual system into a home automation system. This application will automatically turn off the power when the room is empty, judging from the detection of movement in the span of more than 10 minutes. Data collection methods that the author uses is the collection of primary and secondary data consisting of observations, interviews and studies of similar literature. The method of application development is an evolutionary prototype with 4 stages that includes user needs analysis, making a prototype. The result of this research is the implementation of home automation in the form of Room Control System with motion technology for 2 months based on mobile web proved to cause the use of electricity in Cody more efficient based on the ratio of electric bill before and after using the system that the author proposed. This can be seen from the significant change in the cost of electricity that Cody has to pay per month which is $20 \%$ more efficient than without using the proposed system.
\end{abstract}

Keywords: Home Automation, Smart Room, Motion, Mobile Web Application DOI : 10.15408/jti.v11i1.6261 


\section{PENDAHULUAN}

Cody app academy merupakan tempat kursus yang berlokasi di bilangan bintaro, bergerak di bidang edukasi teknologi, khususnya yang berkaitan tentang program pembelajaran di bidang teknik membuat games yang bersifat edukatif, pesertanya terdiri dari anak anak dengan rentang usia 6 sampai dengan 15 tahun. Cody sebagai lembaga kursus memiliki sistem tata kelola yang di jalankan oleh investor dan juga $C E O$ nya. Sistem tata kelola yang di jalankan meliputi banyak hal seperti tata kelola tempat, tata kelola infrastruktur, dan tata kelola operasional.

Dalam hal tata kelola tempat, Cody menyewa sebidang ruangan di dalam sebuah mall di daerah Bintaro, Jakarta selatan, untuk menjalankan bisnisnya sejak tahun 2014. Dari segi tata kelola infrastruktur, Cody melengkapinya dengan beberapa barang, baik elektronik maupun non elektronik, untuk barang non elektronik seperti meja, kursi, dan papan tulis merupakan inventaris yang di berikan oleh investor kepada Cody app academy, sedangkan dalam hal tata kelola operasional barang non elektronik tersebut di lakukan oleh $C E O$ dan juga para staff termasuk para pengajar yang bekerja di Cody.

Untuk tata kelola operasional yang di lakukan Cody terhadap barang elektronik seperti, $L C D T V, A C$, dan Komputer, dijalankan oleh CEO Cody, tata kelola operasional meliputi pembelian, perawatan, dan juga pembiayaan tagihan listrik yang menjadi salah satu pembiayaan rutin yang di lakukan oleh pengelola Cody, jumlah tagihan listrik yang harus dibayar tiap bulan nya bervariasi sesuai dengan pemakaian barang elektronik yang ada, namun berdasarkan wawancara yang penulis lakukan dengan pemilik Cody, besaran biaya tagihan listrik yang harus dikeluarkan Cody cenderung susah untuk dikendalikan karena Cody menggunakan banyak barang elektronik yang menyala secara terus menerus, baik ketika ada orang maupun ketika tidak ada orang sama sekali di dalam ruangan belajar Cody dalam rentang watku operasional, terlebih Cody juga mempunyai jadwal kelas yang berbeda setiap harinya sedangkan seluruh alat elektronik yang ada di dalam ruangan tetap di biarkan menyala.

Berdasarkan wawancara terhadap para pengajar Cody, yakni Okky Permatasari dan Adelia Permatasari, ternyata Cody masih menerapkan cara manual untuk menyalakan dan mematikan listrik, hal ini berdampak terhadap efisiensi penggunaan arus listrik yang ada di Cody, yang berkaitan langsung dengan besar atau kecilnya tagihan listrik yang harus dibayar oleh pengelola Cody. Oleh karena itu menurut CEO Cody App Academy, Bapak Wisnu Sanjaya, sangat diperlukan adanya sistem yang bisa mengatur atau mengontrol kedisiplinan para pengajar Cody sehingga potensi kelalaian untuk mematikan arus listrik ketika ruangan sedang tidak digunakan dapat diminimalisir.

Berkaitan dengan masalah tersebut, Home Automation dapat menjadi bahan pertimbangan, berdasarkan jurnal yang di keluarkan oleh MIT (Massachussets Institue of Technology) yang dibuat oleh Javier Castro dan James Psota, rumah di abad ke 21 akan semakin pintar dan menjadi rumah yang bisa mengendalikan dirinya sendiri, bisa mengenali orang yang masuk atau keluar ruangan dan bahkan menyapa orangorang disekitarnya, hal ini yang bisa menjadi contoh solusi dalam sistem home automation.

Penulis berdiskusi dengan pemilik Cody App Academy yaitu Bapak Narendra Wicaksana dan CEO dari Cody App Academy yaitu bapak Wisnu Sanjaya yang menyimpulkan bahwa Cody membutuhkan sebuah sistem yang memiliki kriteria sebagai Home Automation untuk digunakan dan diimplementasikan di Cody App Academy, selain itu sistem juga dapat mengakomodir pendeteksi gerakan menggunakan Raspberry $P i$, dengan modul yang sudah tersedia dalam Raspberry Pi, bernama motion module. Motion module adalah sebuah program yang ditulis dengan bahasa $\mathrm{C}$ yang berjalan di atas sistem operasi Linux yang berfungsi untuk memonitor sinyal video dari satu atau beberapa kamera, sinyal yang ditangkap berupa gambar dan video yang menggunakan video4linux library dimana program motion ini dapat digunakan sebagai cara atau metode untuk mendeteksi gerakan berdasarkan komparasi dari perubahan pixel pada serangkaian foto atau video yang ditangkap oleh motion modul melalui kamera yang telah terhubung dengan Raspberry $P i$.

Berdasarkan analisis uraian wawancara yang ada, diajukan ide untuk menerapkan motion detect sebagai teknologi yang digunakan untuk membantu menyelesaikan permasalahan yang terjadi di Cody App Academy dengan mengangkat judul penelitian, "Sistem Otomasi Ruangan dengan Raspberry Pi berbasis Mobile Web, Studi Kasus: (Cody App Academy)". 


\section{LANDASAN TEORI}

\subsection{Sistem Home Automation}

Home Automation adalah suatu kontrol dari salah satu atau semua perangkat listrik yang ada di rumah. Home Automation merupakan salah satu perkembangan teknologi yang paling menarik untuk rumah yang sudah diterapkan dalam beberapa tahun ini. Ada ratusan produk yang tersedia saat ini yang memungkinkan pemilik rumah untuk dapat mengendalikan perangkat rumah secara otomatis, baik dengan remote control atau bahkan oleh perintah suara dan pendeteksi gerakan.

Sebuah sistem Home Automation mengintegrasikan perangkat listrik di sebuah rumah dengan satu sama lain. Teknik-teknik yang digunakan dalam Home Automation termasuk yang diotomatisasi bangunan serta pengendalian kegiatan rumah tangga dan penggunaan robot dalam rumah. Home Automation menjadikan perangkat-perangkat rumah dapat dihubungkan melalui jaringan komputer untuk memungkinkan kontrol oleh komputer pribadi dan memungkinkan akses remote dari Internet [1].

\subsection{Motion}

Motion merupakan suatu aplikasi yang mampu memonitoring sinyal video dari sebuah kamera dan mampu mendeteksi perubahan yang terjadi pada potongan video. Motion berkerja secara penuh dalam mode text dan tidak memiliki interface. Motion dikembangkan pertama kali oleh Jeroen Vreeken dan kemudian dilanjutkan oleh Folkert van Heusden dan Kenneth Lavrsen. Aplikasi motion sendiri ditulis menggunakan bahasa $\mathrm{C}$ dan memiliki output berupa gambar jpg ataupun video mpg [2].

Motion bekerja dengan cara membandingkan intesitas pixel dari gambar baru dengan gambar referensi (gambar lama). Dalam proses perbandingan ini warna dalam suatu gambar tidak diperlukan dan hanya diambil citra hitam putihnya saja. Aplikasi motion memiliki fitur antara lain:

\section{Live Streaming Webcam}

Webcam menghasilkan streaming video dalam format MJPEG. Pada webcam_maxrate dan webcam_quality adalah pilihan penting untuk membatasi beban pada server dan link. Tidak disarankan untuk menetapkan nilai terlalu tinggi, kecuali jika hanya ingin menggunakannya pada localhost atau pada LAN internal. Pilihan webcam_quality setara dengan tingkat kualitas untuk jpeg pictures.

2. Capture Gambar Saat Terdeteksi Gerakan

Bagian ini, motion mengontrol bagaimana menghasilkan gambar saat mendeteksi gerakan.

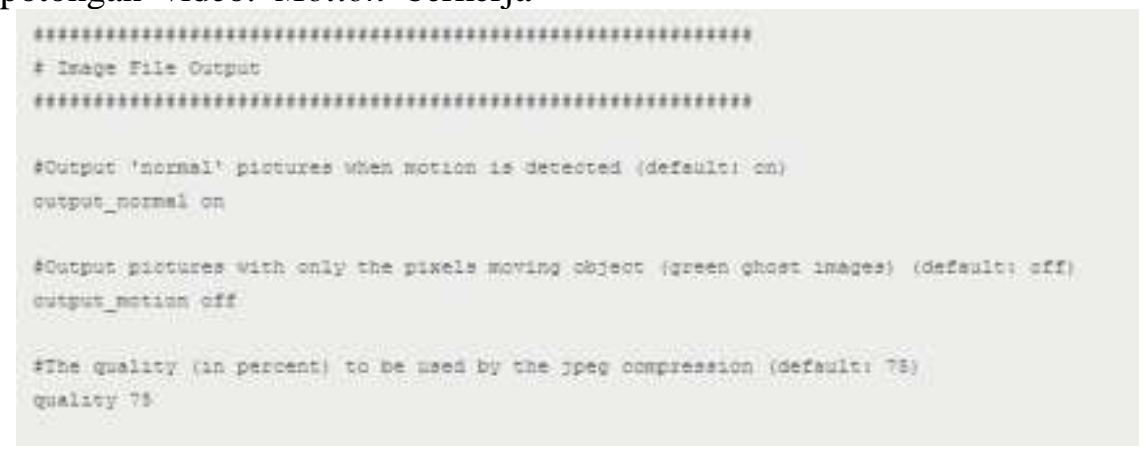

Gambar 1. Pengaturan menangkap gambar dengan motion [2]

\section{Motion Detection}

Motion dapat bekerja melakukan deteksi gerakan atau motion detection. Dalam penggunaannya terdapat beberapa kontrol untuk mendeteksi gerakan. Dalam penelitian ini digunakan kontrol pada area deteksi

- Area deteksi

Mendeteksi daerah gerakan di pusat adalah pengaturan default. Sebuah script (on_area_detected) segera dimulai ketika pusat gerakan terdeteksi di salah satu wilayah yang diberikan. Area diberi nomor seperti pada gambar berikut:

$\begin{array}{lll}1 & 2 & 3 \\ 4 & 5 & 6 \\ 7 & 8 & 9\end{array}$

Gambar 2. Area deteksi gerakan [2]

\section{Threshold}

Ambang batas atau threshold digunakan untuk menyatakan gerak. Ambang batas adalah jumlah piksel yang berubah dihitung 
setelah noise filtering, masking, despeckle, dan labelling.

Pilihan threshold adalah pengaturan deteksi yang paling penting. Ketika gerakan berjalan, threshold akan membandingkan frame gambar ini dengan frame sebelumnya dan menghitung jumlah piksel yang berubah setelah diproses gambar dengan noise filtering, masking, despeckle dan labelling. Jika terjadi perubahan piksel dari yang ditentukan oleh 'ambang' dapat dianggap bahwa telah terdeteksi adanya gerakan [2].

\section{Triggered Command}

Selain untuk mendeteksi gerakan motion juga bisa menindaklanjuti gerakan yang telah terdeteksi dengan berbagai kondisi dimana masing masing kondisi bisa menstimulasi atau sebagai trigger untuk menjalankan baris perintah berupa python code atau bash shell code. Di bawah ini merupakan tabel perintah serta fungsinya yang ada di motion [2].

\section{Raspberry Pi 2 Model B}

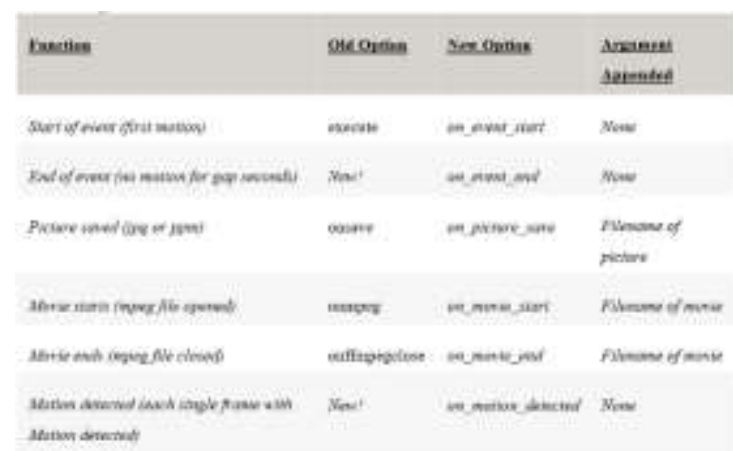

Gambar 3. Triggered command table [2]

\subsection{Raspberry Pi}

Berdasarkan situs resminya di raspberrypi.org, pengertian Raspberry Pi adalah komputer murah berukuran kartu kredit yang dihubungkan ke monitor komputer atau $T V$, dan menggunakan keyboard standar dan mouse. Raspberry $P i$ adalah perangkat kecil yang mampu dan memungkinkan orang dari segala usia untuk mengeksplorasi komputasi, dan belajar bagaimana program dalam bahasa seperti Scratch dan Python. Raspberry Pi mampu melakukan segala sesuatu yang komputer desktop lakukan, dari browsing internet dan bermain video high-definition, untuk membuat spreadsheet, pengolah kata, dan bermain game.

Selain itu, Raspberry $P i$ memiliki kemampuan untuk berinteraksi dengan dunia luar, dan telah digunakan dalam berbagai macam proyek digital.

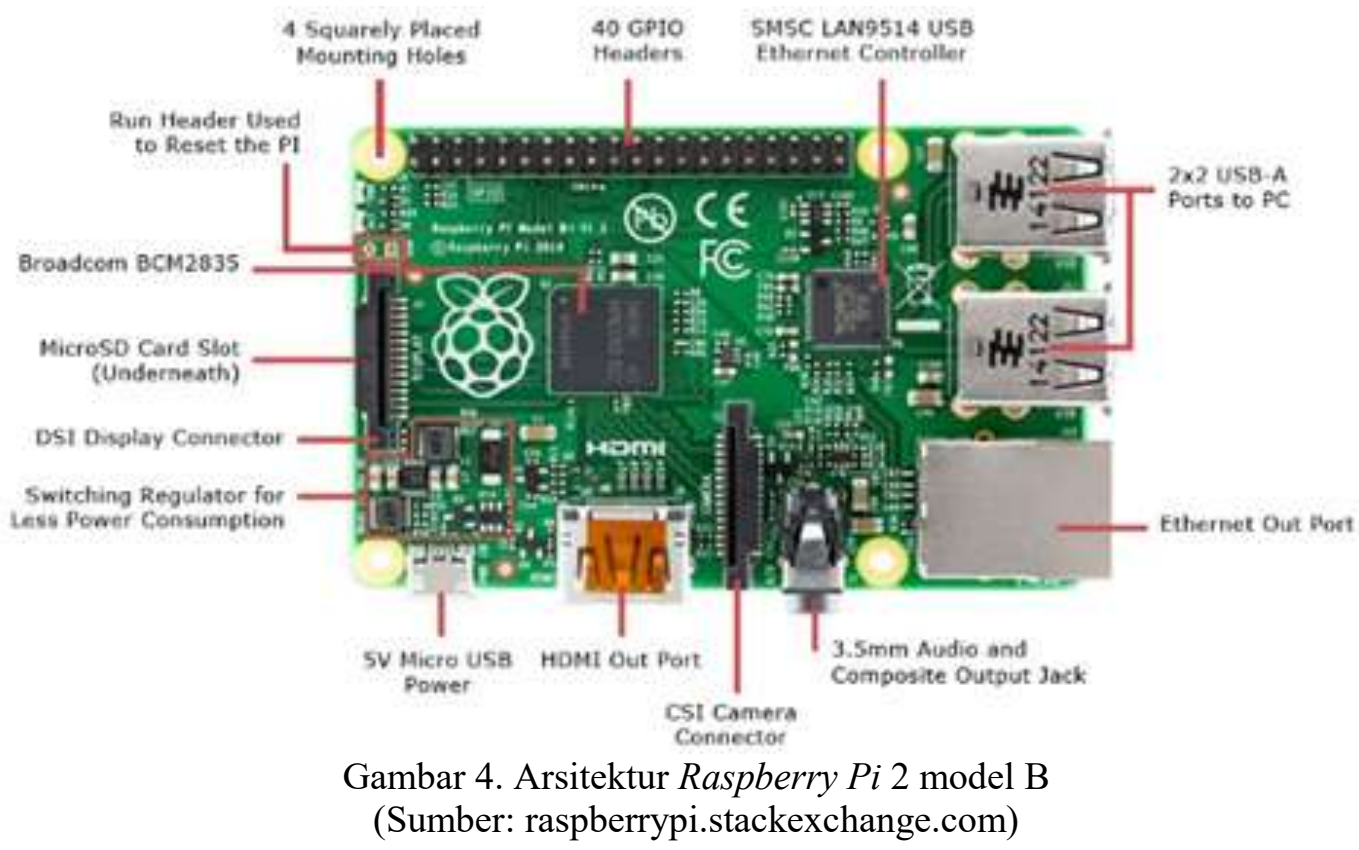

Raspberry Pi 2 memberikan kapasitas 6 kali pengolahan yang lebih cepat dibandingkan dengan generasi sebelumnya. Ini generasi kedua Raspberry $P i$ yang 
memiliki upgrade Broadcom Prosesor BCM2836, yang merupakan ARM CortexA7 yang kuat berbasis quad-core prosesor yang berjalan pada $900 \mathrm{MHz}$. Board ini juga dilengkapi dengan peningkatan kapasitas memori sebesar 1 GByte. Untuk Spesifikasi lebih lengkap dapat dilihat pada tabel-tabel berikut:

Tabel 1. Spesifikasi Raspberry Pi 2 model B (Sumber:http://www.adafruit.com/pdfs/raspberrypi2 modelb.pdf)

\begin{tabular}{|c|c|}
\hline \multicolumn{2}{|r|}{ Specifications } \\
\hline Chip & Broadcom BCM2836 SoC \\
\hline $\begin{array}{c}\text { Core } \\
\text { Architecture }\end{array}$ & Quad-core ARM Cortex-A7 \\
\hline CPU & $900 \mathrm{MHz}$ \\
\hline GPU & $\begin{array}{c}\text { Dual Core VideoCore IV® } \\
\text { Multimedia Co-Processor } \\
\text { Provides Open GL ES 2.0, } \\
\text { hardware-accelerated OpenVG, and } \\
1080 \text { p30 } \\
\text { H.264 high-profile decode } \\
\text { Capable of } 1 \mathrm{Gpixel} / \mathrm{s}, 1.5 \mathrm{Gtexel} / \mathrm{s} \text { or } \\
\text { 24GFLOPs with texture filtering and } \\
\text { DMA infrastructure }\end{array}$ \\
\hline Memory & 1GB LPDDR2 \\
\hline $\begin{array}{l}\text { Operating } \\
\text { System }\end{array}$ & $\begin{array}{c}\text { Boots from Micro SD card, running } \\
\text { a version of the Linux operating } \\
\text { system }\end{array}$ \\
\hline Dimensi & $85 \times 56 \times 17 \mathrm{~mm}$ \\
\hline Power & Micro USB socket $5 \mathrm{~V}, 2 \mathrm{~A}$ \\
\hline
\end{tabular}

Tabel 2. Konektor Raspberry Pi 2 model B (Sumber:http://www.adafruit.com/pdfs/raspberrypi2

\begin{tabular}{|c|c|}
\hline & Connectors \\
\hline Ethernet & 10/100 BaseT Ethernet socket \\
\hline Video Output & HDMI (rev $1.3 \& 1.4)$ \\
\hline Audio Output & 3.5mm jack, HDMI \\
\hline USB & $4 \mathrm{x}$ USB 2.0 Connector \\
\hline \multirow[t]{2}{*}{$\begin{array}{c}\text { GPIO } \\
\text { Connector }\end{array}$} & $\begin{array}{l}\text { 40-pin } 2.54 \mathrm{~mm} \text { (100 mil) } \\
\text { expansion header: } 2 \times 20 \text { strip }\end{array}$ \\
\hline & $\begin{array}{c}\text { Memiliki } 27 \text { GPIO pin dengan } 3,3 \\
\text { V, } 5 \text { V dan GND supply lines }\end{array}$ \\
\hline $\begin{array}{l}\text { Camera } \\
\text { Connector }\end{array}$ & $\begin{array}{l}\text { 15-pin MIPI Camera Serial } \\
\text { Interface (CSI-2) }\end{array}$ \\
\hline JTAG & Not populated \\
\hline \multirow{2}{*}{$\begin{array}{l}\text { Display } \\
\text { Connector }\end{array}$} & $\begin{array}{l}\text { Display Serial Interface (DSI) } 15 \\
\text { way flat flex cable connector }\end{array}$ \\
\hline & $\begin{array}{c}\text { with two data lanes and a clock } \\
\text { lane }\end{array}$ \\
\hline $\begin{array}{l}\text { Memory Card } \\
\text { Slot }\end{array}$ & Micro SDIO \\
\hline
\end{tabular}

\subsection{USB Camera}

Web camera atau yang biasa dikenal dengan webcam, adalah kamera yang gambarnya bisa di akses menggunakan world wide web (www), program instant messaging, atau aplikasi komunikasi dengan tampilan video pada $P C$. Webcam juga digambarkan sebagai kamera video digital yang sengaja didesain sebagai kamera dengan resolusi rendah. USB Camera atau webcam adalah perangkat elektronik pengcapture objek yang digunakan bersamaan dengan $P C$ atau laptop. Dapat dipergunakan untuk komunikasi visual sehingga sesama pengguna dapat saling bertatap muka melalui internet. USB camera banyak diterapkan di rumah atau warnet [3].

Webcam (web camera) adalah sebuah kamera video digital kecil yang dihubungkan ke komputer melalui port USB. Sebuah webcam yang sederhana terdiri dari satu lensa standar yang dipasang pada sebuah papan sirkuit $(P C B)$ untuk menangkap sinyal gambar, casing (cover), termasuk casing depan dan casing samping yang berfungsi untuk menutupi lensa standar, serta memiliki sebuah lubang lensa pada casing depan yang berguna untuk memasukkan gambar.

Ada beberapa metode penyiaran yang biasa dilakukan. Metode yang paling umum adalah menggunakan software yang dapat mengubah gambar menjadi file dengan format JPEG, dan mengunggah ke web server menggunakan File Transfer Protocol (FTP).

Dalam pembahasan webcam, dikenal istilah frame rate yang mengindikasikan jumlah gambar yang dapat diambil dan ditransfer oleh sebuah software dalam satu waktu. Untuk streaming video, dibutuhkan minimal 15 frame per second (fps) atau idealnya 30 fps. Untuk mendapatkan frame rate yang tinggi dibutuhkan koneksi internet dengan kecepatan yang tinggi pula [4].

\subsection{Aplikasi Berbasis Mobile Web}

Menurut situs pcmag.com yang menjelaskan defisini dari aplikasi berbasis mobile web adalah aplikasi yang dijalankan melalui browser pada perangkat smartphone atau perangkat selular lainnya.

Konsep yang mendasari aplikasi web sebenarnya sederhana. Operasi yang melatarbelakanginya melibatkan pertukaran informasi antara komputer yang meminta informasi yang disebut client, dan komputer yang memasok informasi (atau disebut server). Secara lebih detail, server yang melayani 
permintaan dari client sesungguhnya berupa suatu perangkat lunak yang dinamakan webserver. Secara internal, webserver inilah yang berkomunikasi dengan perangkat lunak lain yang disebut middleware dan middleware inilah yang berhubungan dengan database. Model seperti inilah yang mendukung web dinamis. Dengan menggunakan web dinamis, dimungkinkan untuk membentuk aplikasi berbasis web yang berinteraksi dengan database.

\section{METODOLOGI}

\subsection{Metode Pengumpulan Data}

\section{Observasi}

Dilakukan observasi (observation without getting involved) sebanyak 2 kali untuk mengamati secara langsung bagaimana proses pengoprasian alat elektronik. Pengamatan digunakan untuk mengukur jumlah arus yang terpakai dalam sehari jika menggunakan cara yang biasa dilakukan oleh Cody App academy.

Selain itu, dilakukan pengumpulan data-data penunjang yang dibutuhkan dalam penelitian. seperti data tagihan listrik, data berapa banyak siswa, dan lainnya, untuk menjadi tolak ukur atau sebagai pembanding terhadap penelitian yang dilakukan.

\section{Wawancara}

Wawancara dilakukan dengan metode wawancara semi-terstruktur dengan narasumber. Bapak Wishnu selaku CEO dan Ibu Okky Permatasari sebagai Pengajar Cody adalah narasumber yang memberikan informasi dan data terkait penelitian. Wawancara dilakukan dengan mengajukan beberapa pertanyaan yang terkait dengan informasi apakah diperlukan Sistem Pengendali Ruangan untuk membantu Cody menegakkan disiplin dalam menyalakan dan mematikan arus listriknya.

\section{Studi Pustaka dan Litelatur}

Dalam melakukan penelitian, dilakukan pencarian buku-buku sebagai referensi bahan penelitian, selain itu digunakan juga perbandingan jurnal dan perbandingan sistem. Berikut beberapa literatur yang dipakai dalam penelitian:

- Subiyanto, Mochamad. (2013), "Lock Controlling Classroom" [5]

- Pribadi, Indra Pati A. (2012), "Robot Pengintai Menggunakan PC Berbasis Mikrokontroller AT89S51" [6]

- Nurdiana, Haerul. (2014), "Purwarupa Robot Mata-Mata Berbasis Raspberry Pi Pada SMPN 1 Pasarkemis" [7]
- N. Sugumaran, G.V. Vijay (2017), "Smart Surveillance Monitoring System using Raspberry Pi and Pir Sensor" [8]

- Srinidhi Kulkarni, (2017). "IoT Based Home Automation Control System Using Raspberry Pi " [9]

\subsection{Metode Pengembangan Sistem}

Metode pengembangan sistem yang digunakan dalam penelitian ini menggunakan metode Prototyping yang mengacu pada buku Management Information Systems Edition 10th. Metode ini dipilih karena merupakan penyempurnaan dari pendekatan sistem tradisional. Pendekatan ini menyadari adanya keuntungan dari meminta permohonan umpan balik dari pengguna berulang kali dan meresponsnya dengan perbaikan sistem dan tetap meneruskan siklus sampai sistem memenuhi kebutuhan para pengguna.

Metode prototyping evolusioner yang digunakan mencakup 4 tahapan, yaitu:

\section{Mengidentifikasi Kebutuhan Pengguna}

Mengidentifikasi kebutuhan pengguna dengan dilakukan beberapa rangkaian wawancara, membandingkan studi literatur sejenis dan analisis.

Wawancara dilakukan dengan beberapa orang yang terlibat secara langsung dengan operasional dan manajerial dari Cody App Academy. Kemudian hasil dari wawancara direfleksikan kedalam sistem berjalan dan sistem yang akan diajukan dengan maksud sistem yang akan dibuat sesuai dengan kebutuhan pengguna. Selain itu, dilakukan juga analisis software, hardware, dan tools.

\section{Membuat Satu Prototipe}

Setelah dilakukan identifikasi kebutuhan pengguna, dibuat satu prototipe berdasarkan hasil identifikasi kebutuhan pengguna tersebut. Tahap pembuatan prototipe ini disebut dengan tahap desain aplikasi sistem, desain user interface dan pengkodean sistem.

- Desain Aplikasi Sistem

Metode yang digunakan dalam membuat Sistem Pengendali Ruangan ini adalah $U M L$ menurut [10]

\section{- Desain User Interface}

Perancangan yang dilakukan meliputi setiap halaman yang terdapat pada sistem berbasis mobile web application.

- Pengkodean Sistem

Pengkodean sistem dilakukan dengan merepresentasikan bentuk prototype menjadi beberapa file yang terdiri dari baris 
pemrograman yang nantinya akan menjadi fungsi utama dari sistem yan akan dibuat, yaitu kode untuk mendeteksi keberadaan manusia di dalam sebuah ruangan berdasarkan pendeteksian gerakan, selain itu dilakukan juga pengkodean yang ditujukan untuk aplikasi pengontrol yang akan diimplementasikan di smartphone berbasis mobile web application. Dalam melakukan pengkodean digunakan beberapa bahasa pemrograman seperti python, PHP, HTML, CSS dan javascript untuk aplikasi berbasis mobile, adapun untuk pengkodean dan juga konfigurasi micro computer Raspberry Pi, digunakan pemrograman Bash dan juga beberapa script berbasis linux.

\section{Menentukan Apakah Sistem Dapat \\ Diterima}

Dilakukan edukasi kepada pengguna dalam penggunaan prototipe sistem dan memberikan kesempatan bagi pengguna untuk menjadi akrab dengan prototipe sistem. Wawancara juga dilakukan kepada pengguna untuk mengetahui feedback apakah alat sudah sesuai dengan kebutuhan, dan pengguna merasa puas. Selanjutnya dilakukan pengujian dengan menggunakan black-box testing.

Pengujian secara black-box berfokus pada unit program apakah memenuhi kebutuhan (requirement) yang disebutkan dalam spesifikasi dan berjalan sesuai dengan persyaratan fungsional. Cara pengujian dengan menjalankan atau mengeksekusi unit atau modul, kemudian mengamati apakah hasil dari unit sesuai dengan proses bisnis yang diinginkan. Jika hasil feedback dan testing berjalan dengan baik sesuai dengan kebutuhan dan memuaskan, prototipe siap diproduksi dan dapat digunakan sistem operasional.

\section{Menggunakan Prototipe}

Tahapan terakhir dalam prototyping evolusioner adalah menggunakan prototipe. Prototipe sistem pengendalian arus listik dengan smartphone sebagai pengendalinya dan pengendalian tersebut sudah dapat diakses melalui mobile web applications, sudah diterima dan disetujui oleh pengguna, maka siap digunakan untuk pengendalian ruangan menggunakan motion.

\section{HASIL DAN PEMBAHASAN}

Setelah mendapatkan hasil dari identifikasi kebutuhan pengguna yang meliputi wawancara, analisis kebutuhan software maupun hardware, dan juga analisis sistem berjalan dan usulan, penulis dapat menyimpulkan bahwa Sistem Pengendali Ruangan diperlukan untuk membantu Cody menghemat listrik dengan cara mendeteksi keberadaan orang di dalam ruangan dengan motion yang dapat diakses melalui mobile website. Hal ini dimaksudkan agar memenuhi kebutuhan Cody App Academy dalam menegakan disiplin terhadap penggunaan listrik dan penghematan biaya tagihan listrik.

\subsection{Analisis Sistem}

Berikut adalah skema alur dari analisis sistem berjalan menurut hasil wawancara dengan $C E O$ dan juga para pengajar dari Cody App Academy.

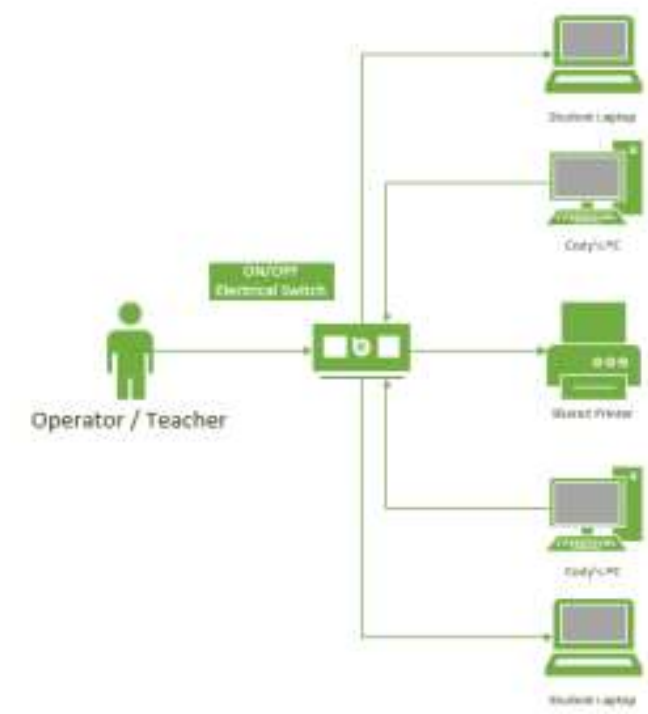

Gambar 5. Sistem berjalan pengendalian listrik

Pengajar harus menyalakan atau mematikan stop kontak ketika mereka menjalankan aktivitas belajar mengajar.

Dari skema alur analisis sistem berjalan diatas, dilakukan pengajuan sistem usulan berdasarkan hasil dari identifikasi kebutuhan dan analisis sistem berjalan tersebut. Digunakan beberapa skema alur dari analisis sistem usulan berupa prototipe Smart Room dengan deteksi gerakan menggunakan Raspberry Pi dengan mobile web.

Berikut adalah gambaran secara garis besar mengenai bagaimana sistem usulan berjalan dan melakukan Sistem Pengendali Ruangan dengan menggunakan Raspberry $P i$ dan dengan menggunakan tools motion module dan switching python code: 


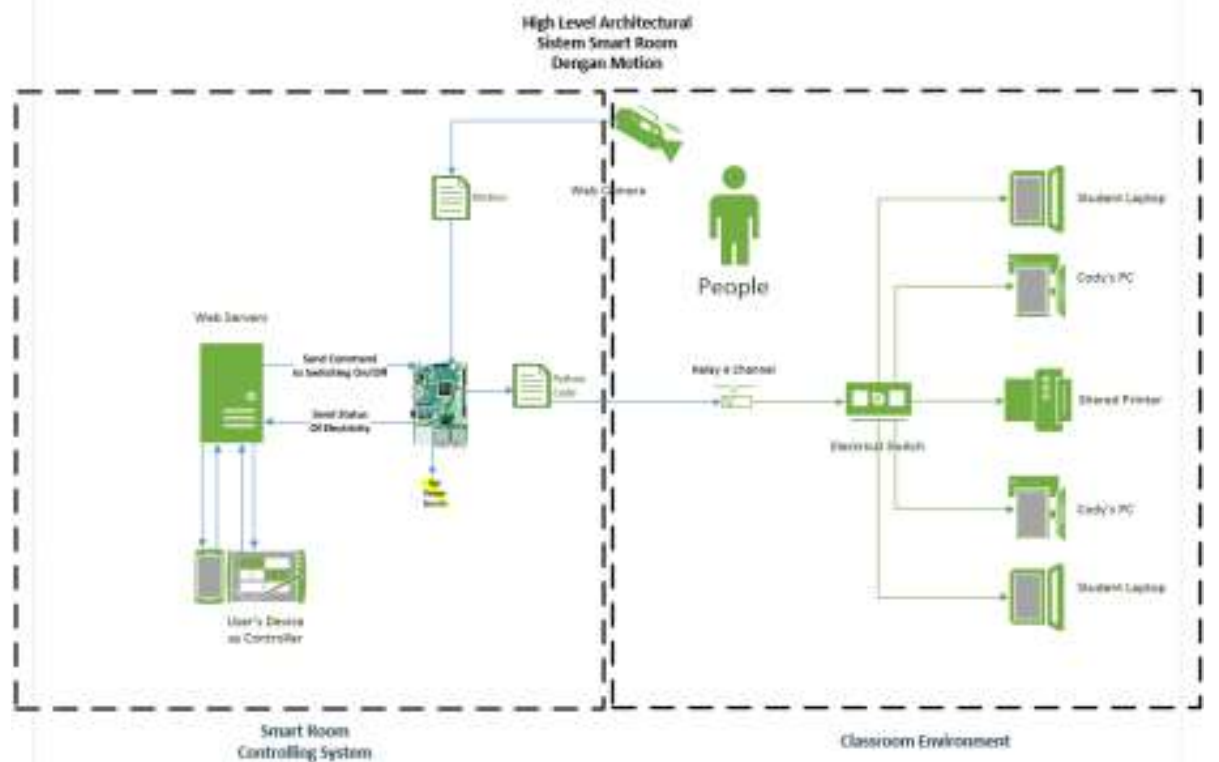

Gambar 6. Sistem usulan smart room pada cody app academy

Berikut adalah penjelasan berdasarkan gambaran secara garis besar di atas:

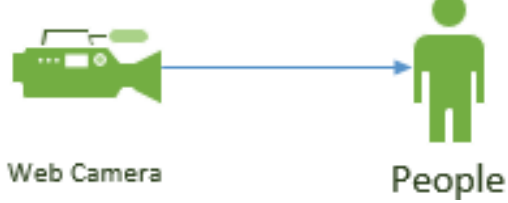

Gambar 7. Arsitektur user

1. Web Camera akan menangkap gambar secara terus-menerus yang kemudian data dari gambar akan dikirimkan ke Raspberry $P i$ melalui USB port.
2. Hasil tangkapan gambar dari webcam akan diproses oleh Raspberry Pi menjadi image capture. Selanjutnya Raspberry Pi juga dapat mendeteksi gerakan dan mengidentifikasinya. Semua proses ini dilakukan dengan tools motion module yang sebelumnya dilakukan installasi terlebih dahulu pada Raspberry Pi. Pada Gambar 4.3 adalah proses yang terjadi pada motion module yang prosesnya dilakukan oleh Raspberry Pi.

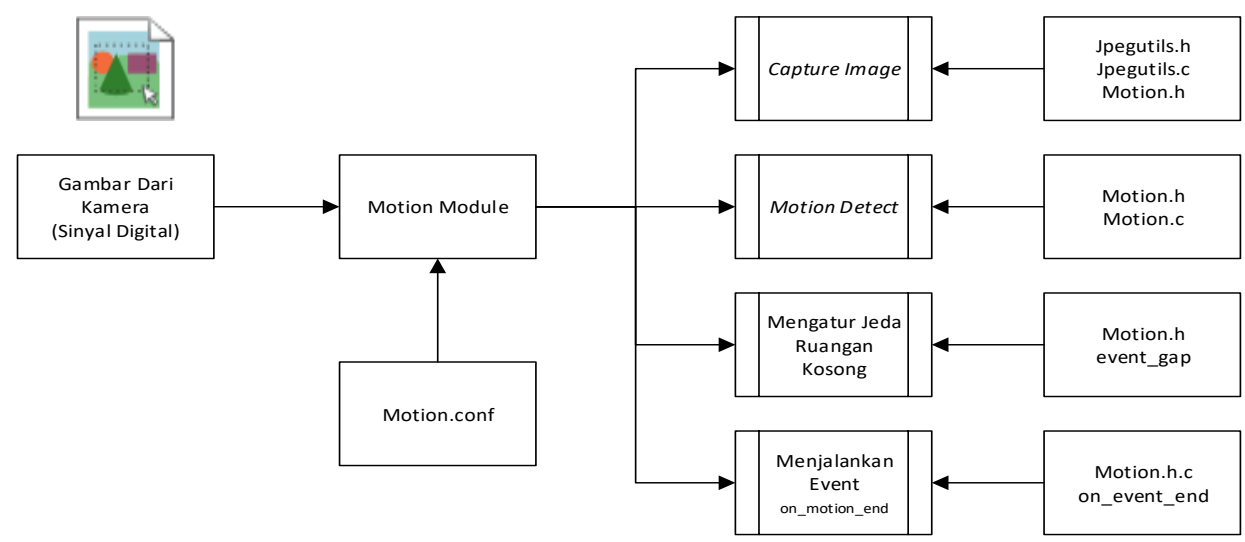

Gambar 8. Proses motion pada Raspberry Pi

- Proses pertama adalah capture image, dalam hal ini motion menjalankan kode jpegutils.h, jpegutils.c, dan motion.h.

- Proses kedua adalah motion detect, dalam hal ini motion menjalankan kode motion.c dan motion.h.
- Proses ketiga adalah menjalankan script berupa konfigurasi yang berada di motion.conf yang mengatur tentang rentang waktu yang dibutuhkan sistem motion untuk mendeteksi kekosongan atau tidak adanya gerakan dalam sebuah ruangan. 
- Proses keempat adalah menjalankan event berupa python script yang dapat digunakan untuk mengontrol on/off pada relay berdasarkan keberadaan orang di dalam ruangan yang dideteksi oleh modul motion kemudian dilanjutkan perubahan status pada relay yang terhubung dengan perangkat elektronik yang ada di Cody App Academy.

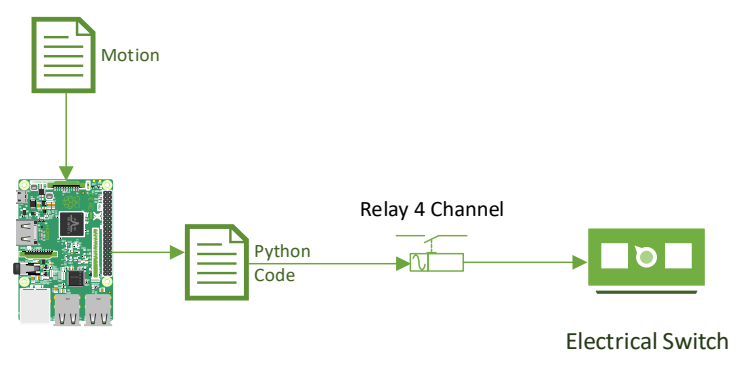

Web Servers

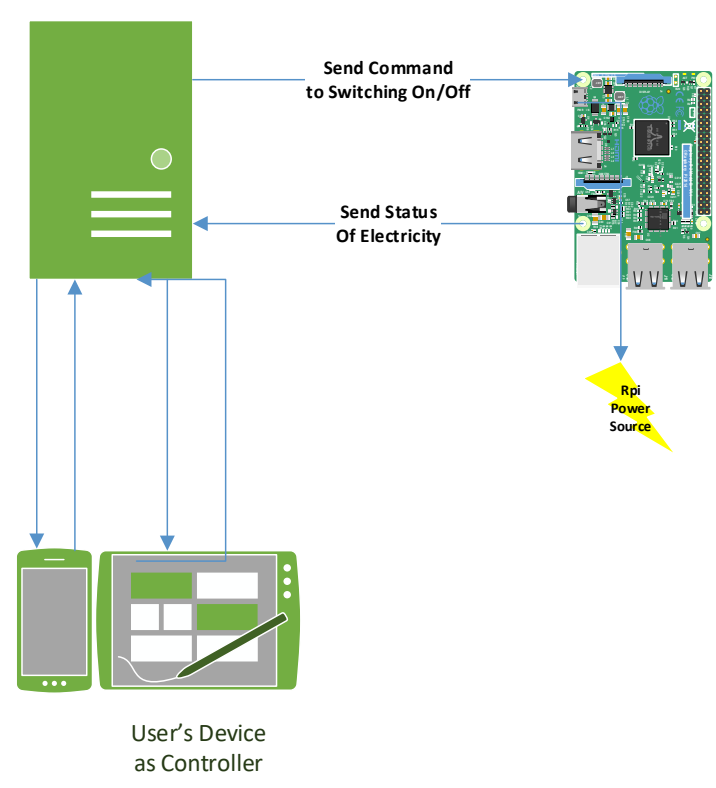

Gambar 9. File konfigurasi
3. Dalam library motion yang dijabarkan di file konfigurasi yang ada pada file motion.conf terdapat triggered command berupa "on_motion_end", yaitu ketika motion tidak lagi mendeteksi adanya gerakan makan motion akan menjalankan event "on_motion_end" yang akan memanggil python code yang digunakan sebagai controller/switch dari Relay 4 channel yang terhubung langsung dengan stop kontak (Electrical Switch).

4. Untuk menghubungkan Sistem Pengendali Ruangan dengan aplikasi berbasis mobile web maka diperlukan sebuah web server, dalam kesempatan kali ini penulis menggunakan localhost sebagai web server, setelah web server selesai di set-up maka raspberry akan mengirimkan status ke aplikasi mobile web tersebut, di lain sisi mobile web juga bisa mengirimkan sinyal kepada Raspberry Pi untuk mematikan atau menyalakan relay yang sudah dihubungkan dengan Raspberry Pi.

Berikut adalah skema alur proses yang lebih detil dari setiap proses yang dilakukan oleh motion module.

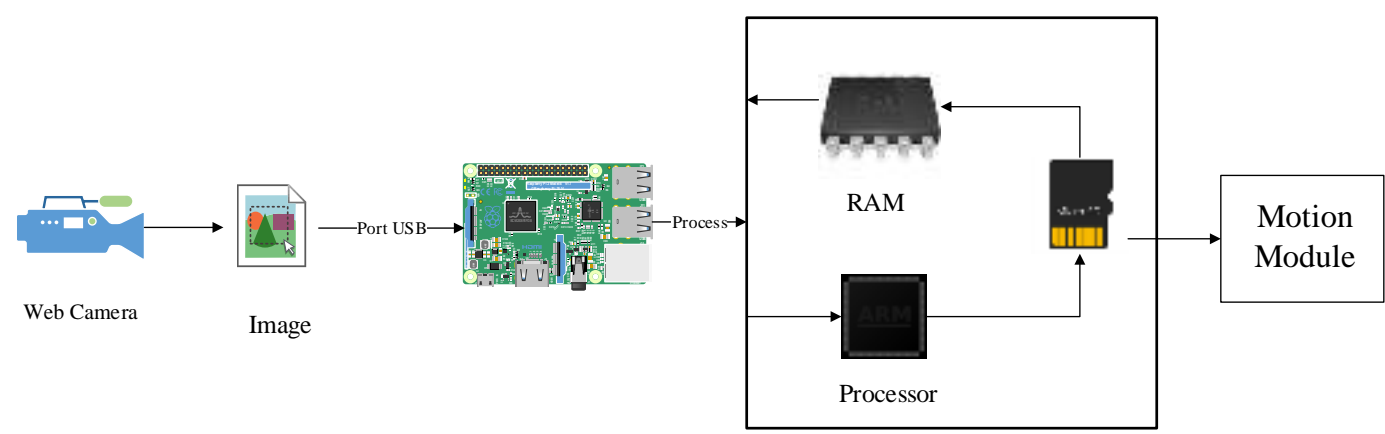

Gambar 10. Proses pada motion.conf

1. Web Camera akan menangkap gambar yang mempunyai sinyal analog. Saat ditangkap, gambar dengan sinyal analog diproses webcam sehingga menjadi sinyal 
digital dan kemudian dikirim ke Raspberry Pi melalui USB port.

2. Di dalam Raspberry Pi, gambar dikirim ke prosesor dan kemudian diolah dengan motion module yang telah diinstal sebelumnya dan tersimpan pada micro sd. Setelah diproses oleh motion, gambar akan ditampilkan kembali berupa sinyal digital, dalam proses ini juga melibatkan RAM yang merupakan tempat penyimpanan sementara. Hasil tangkapan gambar oleh webcam akan diproses menggunakan motion module yang dapat dilakukan pada motion.conf.

\subsection{Smart Room Home Automation}

Home automation adalah salah satu perkembangan teknologi yang menarik yang bisa diterapkan di rumah, namun dalam peelitian ini berdasarkan kebutuhan dari tempat penelitian yaitu Cody App Academy, dilakukan wawancara dengan $C E O$ dan para pengajar yang bekerja di Cody App Academy, yang hasilnya dapat mengakomodir kebutuhan dari Cody App Academy akan efisiensi penggunaan arus listrik dan mengakomodir kelalaian yang dilakukan oleh para pengajar Cody. Berikut adalah penjelasan dari poin-poin yang berhasil diakomodir:

\section{Sistem Pengendali Ruangan}

Menggunakan sistem home automation berarti telah mengintegrasikan perangkat listrik yang ada di dalam sebuah ruangan satu sama lain, dalam studi kasus Cody App Academy, digunkan Web Camera sebagai input dari Sistem Pengendali Ruangan, selanjutnya proses menggunakan teknologi motion yang sudah terinstal pada Raspberry $P i$, dan sebagai keluaran atau output digunakan script python yang bisa mengontrol relay 4 chanel yang berfungsi sebagai penyambung atau pemutus arus.

Selain itu di dalam proses sistem tersebut, terdapat teknologi motion yang berfungsi sebagai trigger atau pemicu dari Sistem Pengendali Ruangan.

\section{Konfigurasi Smart Room}

Sistem yang dibuat membutuhkan sebuah sesi dimana user atau pengguna bisa mengatur Sistem Pengendali Ruangan sesuai dengan keadaan yang ada di ruang kelas dari Cody App Academy, konfigurasi yang bisa dilakukan oleh Raspberry Pi melalui motion.conf meliputi banyak aspek, mulai dari sensistivitas motion module dalam mendeteksi gerakan yang bisa diatur dengan threshold dari gambar yang ditangkap, maupun dengan pengaturan resolusi gambar yang ditangkap oleh web camera, sehingga sistem yang dikembangkan oleh penulis mempunyai fitur deteksi gerakan yang baik.

Selain konfigurasi standar yang menyangkut tentang kualitas atau sensitivitas dari sistem yang dibuat, terdapat beberapa konfigurasi yang fungsinya sangat penting terkait dengan Sistem Pengendali Ruangan atau home automation, fitur konfigurasi tersebut adalah event_gap dan on_event_end, dalam fitur event_gap, sistem dapat mengatur seberapa lama bisa membaca keadaan ruangan yang kosong atau tidak ada gerakan sama sekali, sedangkan pada on_even_end perintah yang akan dieksekusi adalah on_even_end akan menjalankan perintah tertentu jika sudah memenuhi kondisi, dalam hal ini ketika sudah tidak terdeteksi lagi gerakan dalam jangka waktu tertentu, jangka waktu yang dibutuhkna on_event_end adalah nilai dari event gap.

Tabel 3. Perbandingan pengaturan motion conf pada sistem otomasi ruangan di Cody App Academy

\begin{tabular}{|c|c|c|c|}
\hline $\begin{array}{c}\text { Konfigurasi } \\
\text { Motion }\end{array}$ & $\begin{array}{c}\text { Pengaturan } \\
1\end{array}$ & $\begin{array}{c}\text { Pengaturan } \\
2\end{array}$ & $\begin{array}{c}\text { Pengaturan } \\
3\end{array}$ \\
\hline Frame Per Sec & $30 \mathrm{Fps}$ & $25 \mathrm{Fps}$ & $20 \mathrm{Fps}$ \\
\hline Quality & $100 / 100$ & $75 / 100$ & $75 / 100$ \\
\hline Threshold & 3000 & 4000 & 3500 \\
\hline Video Library & YUVCY & YUVCY & YUVCY \\
\hline Motion Area & Centered & $\begin{array}{c}\text { Upper Left } \\
\text { Corner }\end{array}$ & Centered \\
\hline \multicolumn{4}{|c|}{ HASIL } \\
\hline $\begin{array}{l}\text { Deteksi } 1 \\
\text { (Objek Berjalan } \\
\text { Lambat) }\end{array}$ & $\begin{array}{c}\text { Objek } \\
\text { Terdeteksi }\end{array}$ & $\begin{array}{c}\text { Objek } \\
\text { Terdeteksi }\end{array}$ & $\begin{array}{c}\text { Objek } \\
\text { Terdeteksi }\end{array}$ \\
\hline $\begin{array}{l}\text { Deteksi } 2 \\
\text { (Objek Berjalan } \\
\text { Sedikit Cepat) }\end{array}$ & $\begin{array}{c}\text { Objek } \\
\text { Terdeteksi }\end{array}$ & $\begin{array}{c}\text { Objek } \\
\text { Terdeteksi }\end{array}$ & $\begin{array}{c}\text { Objek } \\
\text { Terdeteksi }\end{array}$ \\
\hline $\begin{array}{l}\text { Deteksi } 3 \\
\text { (Objek Berjalan } \\
\text { Cepat) }\end{array}$ & $\begin{array}{c}\text { Objek } \\
\text { Terdeteksi }\end{array}$ & $\begin{array}{c}\text { Objek Tidak } \\
\text { Terdeteksi }\end{array}$ & $\begin{array}{c}\text { Objek } \\
\text { Terdeteksi }\end{array}$ \\
\hline $\begin{array}{l}\text { Deteksi } 4 \\
\text { (Objek Berjalan } \\
\text { Sangat Cepat) }\end{array}$ & $\begin{array}{c}\text { Objek } \\
\text { Terdeteksi }\end{array}$ & $\begin{array}{c}\text { Objek Tidak } \\
\text { Terdeteksi }\end{array}$ & $\begin{array}{c}\text { Objek } \\
\text { Terdeteksi }\end{array}$ \\
\hline $\begin{array}{l}\text { Deteksi } 5 \\
\text { (Objek Berlari) }\end{array}$ & $\begin{array}{c}\text { Objek } \\
\text { Terdeteksi }\end{array}$ & $\begin{array}{c}\text { Objek Tidak } \\
\text { Terdeteksi }\end{array}$ & $\begin{array}{c}\text { Objek } \\
\text { Terdeteksi }\end{array}$ \\
\hline
\end{tabular}

\subsection{Motion Detect}

Fungsi utama dari home automation adalah mengendalikan serangkaian sistem elektronika di dalam sebuah rumah (home) atau ruangan (room) dengan menggunakan trigger atau pemicu berupa voice command, remote control, dan motion detect. 
Berdasarkan hal tersebut, diterapkan fitur motion detection (pendeteksi gerakan) pada penelitian yang dilakukan di Cody App Academy, dan berdasarkan analisis kebutuhan pengguna yang didapatkan dari wawancara dan studi literatur, maka dapat dikatakan bahwa motion detect merupakan salah satu fitur utama dari penelitian yang berfungsi sebagai pemicu atau trigger dari serangkaian proses yang ada di dalam Sistem Pengendali Ruangan.

\subsection{Mobile Web}

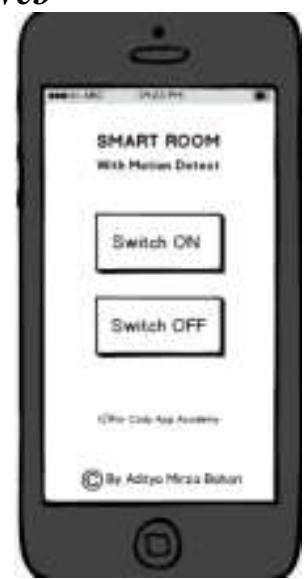

Gambar 11. Mock up smart room mobile apps

Mobile Web Application adalah sebuah salah satu fitur yang disediakan dalam Sistem Pengendali Ruangan, fitur ini merupakan pengendali manual yang bisa menggantikan Sistem Pengendali Ruangan untuk berjaga-jaga jika terjadi kegagalan dalam Sistem Pengendali Ruangan yang berdasarkan pada keberadaan suatu gerakan dalam sebuah ruangan dalam jangka waktu tertentu yang prosesnya dapat berjalan secara otomatis.

Digunakan Raspberry Pi sebagai alat atau otak dari sistem yang dikembangkan, alat ini bertugas untuk memproses semua kegiatan yang diperlukan dalam melakukan Sistem Pengendali Ruangan. Raspberry $P i$ membutuhkaan camera usb untuk melakukan penangkapan gambar, yang kemudian diproses dengan motion module untuk mendeteksi gerakan. Dalam upaya pembuatan sistem dapat diakses online dengan mobile web, digunakan kabel LAN dan ngrok module yang sebelumnya dilakukan instalasi terlebih dahulu pada Raspberry Pi. Power source micro USB dengan 5V 2.0 A diperlukan untuk memberikan power pada Raspberry $P i$ sehingga dapat menyala dan melakukan proses pemantauan dengan baik dan sesuai dengan kebutuhan.

\subsection{Deteksi Gerakan Event_Gap}

Fitur utama dalam Sistem Pengendali Ruangan ini adalah melakukan pemantauan dengan media video streaming untuk mendeteksi gerakan. Pendeteksian akan dilakukan secara terus menerus ketika ada gerakan di dalam ruangan yang mengindikasikan adanya orang di dalam ruangan yang berarti ruangan tesrebut sedang digunakan, setelah ruangan tidak di gunakan atau gerakan sudah tidak terdeteksi, maka event_gap akan mulai menghitung detik demi detik hingga mencapai value yang di atur di event_gap yang ada di moiton.conf.

Jika event_gap telah mencapai value yang ditentukan maka script lain yang bernama on_event_end akan berjalan, dimana pada sistem yang dibuat on_event_end berfungsi untuk memanggil script python yang gunanya untuk mematikan relay, berdasarkan hasil pegujian yang telah dilakukan dapat diketahui bahwa script python berhasil terpanggil ketika ruangan ditinggalkan selama 15 menit. Hal tersebut mendapat tanggapan positif dari $C E O$ Cody Bapak Wisnu Sanjaya, beliau mengatakan bahwa sistem yang diterapkan di Cody App Academy sesuai dengan ekspektasi dan kebutuhan dari Coddy App Academy.

Tabel 4. Hasil pengujian sistem terhadap

kegiatan menyalakan dan mematikan lampu

dengan perbandingan antara waktu pada Camera dan pada PHP Script

\begin{tabular}{ccc}
\hline Kegiatan & Camera & PHP Script \\
\hline Menyalakan Lampu & 1 Detik & 1.25 Detik \\
Mematikan Lampu & 1 Detik & 1.3 Detik \\
\hline
\end{tabular}

\section{KESIMPULAN DAN SARAN}

\subsection{Kesimpulan}

Berdasarkan pembahasan yang sudah diuraikan, maka dapat ditarik kesimpulan bahwa Sistem Pengendali Ruangan dapat membantu Cody App Academy dalam menegakan disiplin untuk mematikan barang barang elektronik ketika sedang tidak digunakan yang berimplikasi dengan menurun nya tagihan listrik bulanan yang harus dibayarkan oleh pengelola Cody App Academy. Sistem Pengendali Ruangan dapat memberikan perintah kepada relay untuk mematikan arus listrik dengan trigger motion detect yang terdapat dalam fitur teknologi motion.

Trigger motion detect diatur dalam sebuah file konfigurasi bernama motion.conf, yang di dalamnya terdapat dua script yang berfungksi 
untuk mengeksekusi perintah yang akan di proses oleh raspberry dan mengatur delay waktu yang dibutuhkan untuk Sistem Pengendali Ruangan mengeksekusi perintah. Sistem Pengendali Ruangan menggunakan motion module dengan fungsi pendeteksian gerakan yang dideteksi dan ditangkap oleh web camera yang telah terhubung dengan Raspberry $P i$. Sistem Pengendali Ruangan menggunakan ngrok module untuk mempublikasikan file html dan $p h p$ yang nantinya akan diakses melalu smartphone dengan format mobile web application. Sistem Pengendali Ruangan bisa diakses dengan smartphone yang berfungsi sebagai pengatur nyala atau mati nya relay listrik secara manual.

\subsection{Saran}

Setelah dibuatnya Sistem Pengendali Ruangan ini, terdapat beberapa saran untuk pembaca dan pengembang selanjutnya, yaitu dalam pengembangan selanjutnya untuk memenuhi sistem home automation trigger yang digunakan bisa lebih variatif misalnya menggunakan voice command. Untuk pengembangan selanjutnya Sistem Pengendali Ruangan bisa menggunakan kamera yang resolusinya lebih tinggi sehingga hasil yang didapat bisa lebih akurat.

Pengembangan selanjutnya juga disarankan untuk membuat sebuah aplikasi berbasis Android maupun iOS demi mengikuti perkembangan zaman dan secara fungsionalitas lebih stabil. Saran untuk fitur yang ada di smartphone, button tidak hanya mempunyai fungsi untuk trigger mengirimkan command, tapi bisa bertindak sebagai actor. Seharusnya sistem sudah menggunakan web server sendiri sehingga user yang menggunakan bisa mengakses smart room dari mana saja dengan menggunakan public DNS. Kemudian seharusnya dibuat stardarisasi dari Sistem Pengendali Ruangan sehingga sistem ini bisa digunakan di berbagai jenis tempat.

\section{DAFTAR PUSTAKA}

[1] PT Golden Solution Indonesia. 2012. Home Automation. http://www.homeautomation.co.id/

[2] Lavrsen. 2013. Legacy Motion Guide for Motion.

http://www.lavrsen.dk/foswiki/bin/view/ Motion/MotionGuide3x1x20
[3] Mahmud Aryanto. 2010. IP Camera dan Aplikasinya. Jakarta: PT Elex Media Komputindo.

[4] Wijaya Ariana, Deni Arifianto. 2009. Cara Top Bikin Komputer Top. Jakarta: PT Kawan Pustaka

[5] Mochamad Subianto. 2013. Rancang Bangun Sistem Lock and Controlling Class Rooms (Lccr) Berbasis Raspberry $P i$. Yogyakarta. Universitas Gajah Mada

[6] Indra Pati Andhika Pribadi. 2012. Robot Pengintai Menggunakan PC Berbasis Mikrokontroller AT89S51.

[7] Haerul Nurdiana. 2014. Purwarupa Robot Mata-Mata Berbasis Raspberry Pi Pada SMPN 1 Pasarkemis.

[8] N. Sugumaran, G.V. Vijay (2017), "Smart Surveillance Monitoring System using Raspberry $P i$ and Pir Sensor".

[9] Srinidhi Kulkarni, (2017). "IoT Based Home Automation Control System Using Raspberry Pi".

[10] Whitten L, Jeffery, Bentley D, Lonnie, Dittman C, Kevin, 2004. Metode Desain dan Analisis Sistem. Terjemahan oleh Tim Penerjemah ANDI. 2004. Yogyakarta: ANDI. 